Article

\title{
Purification of an Antifungal Peptide from Seeds of Brassica oleracea var. gongylodes and Investigation of Its Antifungal Activity and Mechanism of Action
}

\author{
Caicheng Wang $1,2,3$, Yao Zhang ${ }^{1,2,3}$, Weiwei Zhang ${ }^{1,2,3}$, Susu Yuan ${ }^{1,2,3}$, Tzibun Ng ${ }^{4}$ \\ and Xiujuan Ye ${ }^{1,2,3, *}$ \\ 1 State Key Laboratory of Ecological Pest Control for Fujian and Taiwan Crops, Fujian Agriculture \\ and Forestry University, Fuzhou 350002, China; mustardboat@gmail.com (C.W.); zyao797@gmail.com (Y.Z.); \\ weicheung1993@gmail.com (W.Z.); 2140215002@fafu.edu.cn (S.Y.) \\ 2 Key Laboratory of Biopesticide and Chemical Biology, Ministry of Education, Fujian Agriculture \\ and Forestry University, Fuzhou 350002, China \\ 3 Fujian Key Laboratory of Plant Virology, Institute of Plant Virology, Fujian Agriculture \\ and Forestry University, Fuzhou 350002, China \\ 4 School of Biomedical Sciences, Faculty of Medicine, The Chinese University of Hong Kong, \\ Hong Kong 999077, China; b021770@mailserv.cuhk.edu.hk \\ * Correspondence: xiujuanye2004@gmail.com; Tel.: +86-591-83789121
}

Academic Editor: Marcello Locatelli

Received: 16 March 2019; Accepted: 2 April 2019; Published: 4 April 2019

\begin{abstract}
In this study, a 8.5-kDa antifungal peptide designated as BGAP was purified from the crude extract of the seeds of Brassica oleracea var. gongylodes by employing a protocol that comprised cation exchange chromatography on SP-Sepharose, cation exchange chromatography on Mono S and gel filtration chromatography on Superdex peptide. BGAP showed the highest amino acid sequence similarity to defensin peptides by mass spectrometric analysis. BGAP showed a broad spectrum of antifungal activity with a half maximal inhibitory concentration at $17.33 \mu \mathrm{g} / \mathrm{mL}, 12.37 \mu \mathrm{g} / \mathrm{mL}$, $16.81 \mu \mathrm{g} / \mathrm{mL}$, and $5.60 \mu \mathrm{g} / \mathrm{mL}$ toward Colletotrichum higginsianum, Exserohilum turcicum, Magnaporthe oryzae and Mycosphaerella arachidicola, respectively. The antifungal activity of BGAP remained stable (i) after heat treatment at $40-100{ }^{\circ} \mathrm{C}$ for $15 \mathrm{~min}$; (ii) after exposure to solutions of $\mathrm{pH} 1-3$ and $11-13$ for $15 \mathrm{~min}$; (iii) after incubation with solutions containing $\mathrm{K}^{+}, \mathrm{Ca}^{2+}, \mathrm{Mg}^{2+}, \mathrm{Mn}^{2+}$ or $\mathrm{Fe}^{3+}$ ions at the concentrations of $20-150 \mathrm{mmol} / \mathrm{L}$ for $2 \mathrm{~h}$; and (iv) following treatment with $10 \%$ methyl alcohol, $10 \%$ ethanol, $10 \%$ isopropanol or $10 \%$ chloroform for $2 \mathrm{~h}$. Fluorescence staining experiments showed that BGAP brought about an increase in cell membrane permeability, a rise in reactive oxygen species production, a decrease in mitochondrial membrane potential, and an accumulation of chitin at the hyphal tips of Mycosphaerella arachidicola.
\end{abstract}

Keywords: Brassica oleracea var. gongylodes; antifungal peptide; purification

\section{Introduction}

Plants are often attacked by fungi during growth. Infection by pathogenic fungi produces a deleterious effect on plant growth and may even cause death, ensuing in a plummeting of grain yield [1,2]. The release of certain mycotoxins during the infection process poses a tremendous threat to the safety of agricultural products $[3,4]$. Although various plant protection strategies such as comprehensive management and ecological management have been proposed, in practice, chemical control remains as the main preventive and control measure for plant diseases [5,6]. Although chemical agents demonstrate certain control effects on a variety of phytopathogenic fungi, the current practice of the use of chemicals is marred by drawbacks. It not only brings about serious environmental pollution 
and gives rise to the presence of the residues of these chemicals in agricultural products [7], it also aggravates the issue of fungicide resistance [5,8]. Thus, it is of utmost importance to screen for new antifungal substances characterized by safety, high efficiency, environmental friendliness, and lower fungicide resistance. Among the candidates, antifungal peptides have considerable application potential and attracted attention [9-12].

Antifungal activity has been detected in a diversity of living organisms including microbes, animals and plants, and antifungal peptides have been isolated from them [13-15]. For the sake of safety and availability, in our search for antifungal peptides, we have looked more at plants that have long been used as foods. Antifungal peptides, which are important components of plant defense systems, are distributed in the fruits, flowers, leaves, tubers, radicles, and seeds of plants [13,16-21], among which peptides derived from seeds are more common. At the early stage of this research, we performed assays of antifungal activity on crude protein extracts from various plant seeds and discovered that the crude protein extract of Kohlrabi (Brassica oleracea var. gongylodes) seeds exhibited good antifungal activity against various phytopathogenic fungi. Consequently, in this study, we purified and characterized the antifungal peptide from Kohlrabi seeds extract, studied its antifungal activity and stability, and investigated its effects on pathogenic fungi, with the intent to provide a basis for further unraveling the mechanism of action of the antifungal peptide and broadening the scope of its application.

\section{Results}

Fraction SP3 with antifungal activity was obtained by cation exchange chromatography of the crude protein extract of Kohlrabi seed extract on SP-Sepharose (Figure 1a). The active fraction MS3 was obtained from fraction SP3 by cation exchange chromatography on Mono S (Figure 1b). The active fraction SU3 was obtained from fraction MS3 by gel filtration chromatography on Superdex peptide (Figure 1c). Fractions not mentioned above did not have antifungal activity. Fraction SU3 contained a highly-purified antifungal peptide, which was named BGAP which showed a molecular weight of about $8.5 \mathrm{kDa}$ in SDS-PAGE (Figure 1d) and was found to have reliable similarity with defensins and thionins by MALDI-TOF/TOF MS analysis, and had the highest similarity with defensin-like protein 1 from Brassica oleracea var. oleracea (Table 1). The defensin peptides listed in the table are peptides predicted by genomic sequences; the details can be obtained from the protein database of the NCIB database according to the accession No. provided in Table 1.

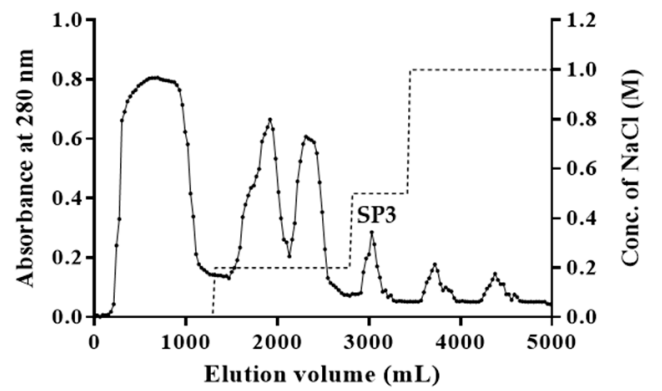

(a)

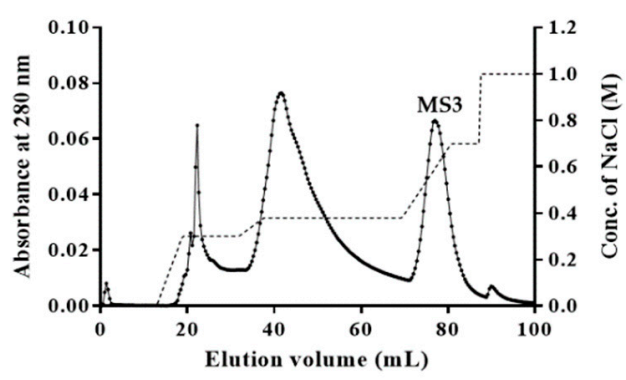

(b)

Figure 1. Cont. 


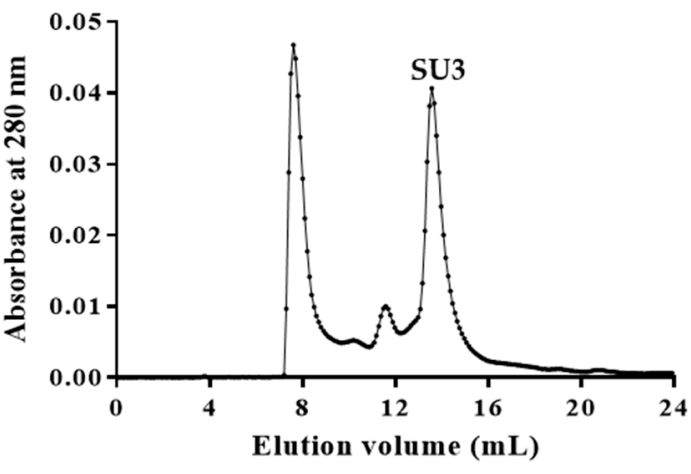

(c)

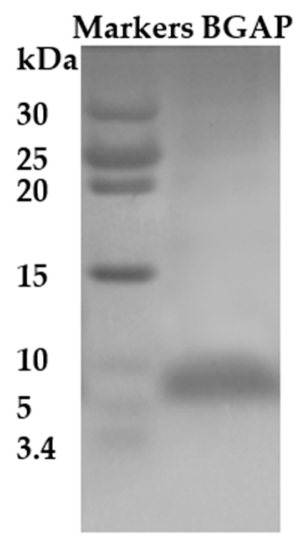

(d)

Figure 1. Purification and molecular weight determination of BGAP: (a) cation exchange chromatography of crude protein extract on SP-Sepharose column: (-): absorbance at $280 \mathrm{~nm},(\ldots$ ): concentration of $\mathrm{NaCl}$; (b) cation exchange chromatography of active fraction SP3 from SP-Sepharose column on Mono S column;

(c) gel filtration chromatography of active fraction MS3 from Mono S column on Superdex peptide column;

(d) Tricine-SDS-PAGE of active fraction SU3 from Superdex peptide column.

Table 1. MALDI-TOF/TOF MS results of various peptides derived from BGAP.

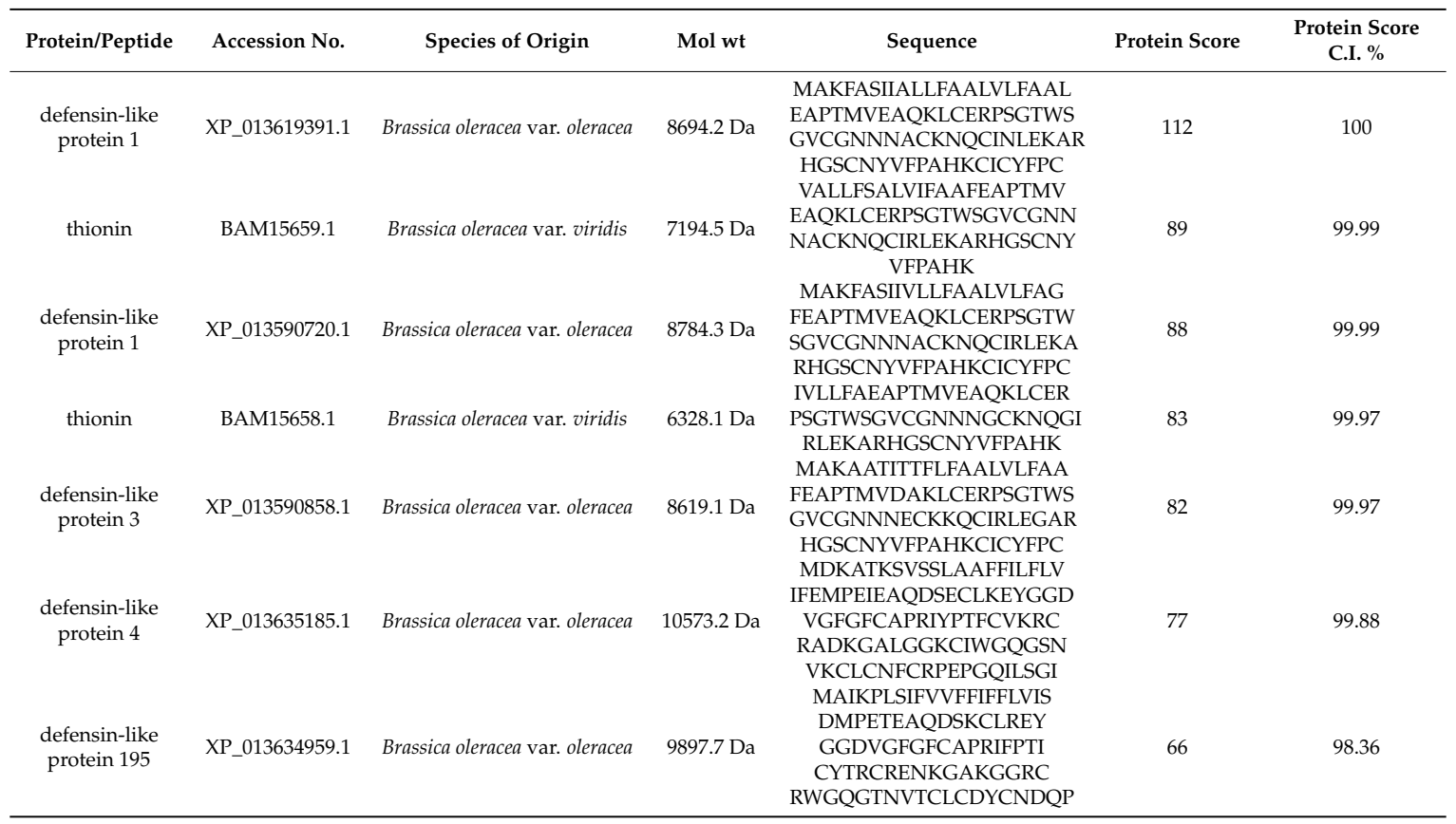

The assay of antifungal activity disclosed that BGAP manifested potent growth inhibitory activity against the following 12 phytopathogenic fungi encompassing Alternaria longipes, Botrytis cinerea, Colletotrichum gloeosporioides, C. higginsianum, Exserohilum turcicum, Fusarium oxysporum, F. solani f. sp. glycines, Helminthosporium maydis, Magnaporthe oryzae, Mycosphaerella arachidicola, Pestalotiopsis microspora, and Valsa mali, but expressed only weak activity against F. graminearum and C. micotianae (Figure 2). BGAP was devoid of growth retarding effect on the eight bacteria tested including Bacillus subtilis, Erwinia carotovora, Escherichia coli, Pseudomonas aeruginosa, P. pseudoalcaligenes, Ralstonia solanacearum, Salmonella sp., and Staphylococcus aureus. The determination of half maximal inhibitory concentration $\left(\mathrm{IC}_{50}\right)$ was performed (Figure 3). The $\mathrm{IC}_{50}$ values of BGAP toward Colletotrichum higginsianum, Exserohilum turcicum, Magnaporthe oryzae, and Mycosphaerella arachidicola were $17.33 \mu \mathrm{g} / \mathrm{mL}, 12.37 \mu \mathrm{g} / \mathrm{mL}, 16.81 \mu \mathrm{g} / \mathrm{mL}$, and $5.60 \mu \mathrm{g} / \mathrm{mL}$, respectively. The pronounced 
stability of the antifungal activity of BGAP was observedafter heat treatment at $40-100{ }^{\circ} \mathrm{C}$ for 15 min (Figure 4A); after treatment with acid-base solutions of pH 1-3 and 11-13 for 15 min (Figure 4B); following exposure to solutions containing $\mathrm{K}^{+}, \mathrm{Ca}^{2+}, \mathrm{Mg}^{2+}, \mathrm{Mn}^{2+}$ or $\mathrm{Fe}^{3+}$ ions at 20-150 mmol/L for $2 \mathrm{~h}$ (Figure $4 \mathrm{C}-\mathrm{G}$ ), andafter treatment with methanol, ethanol, isopropanol, and chloroform at a concentration of $10 \%$ (Figure $4 \mathrm{H})$.

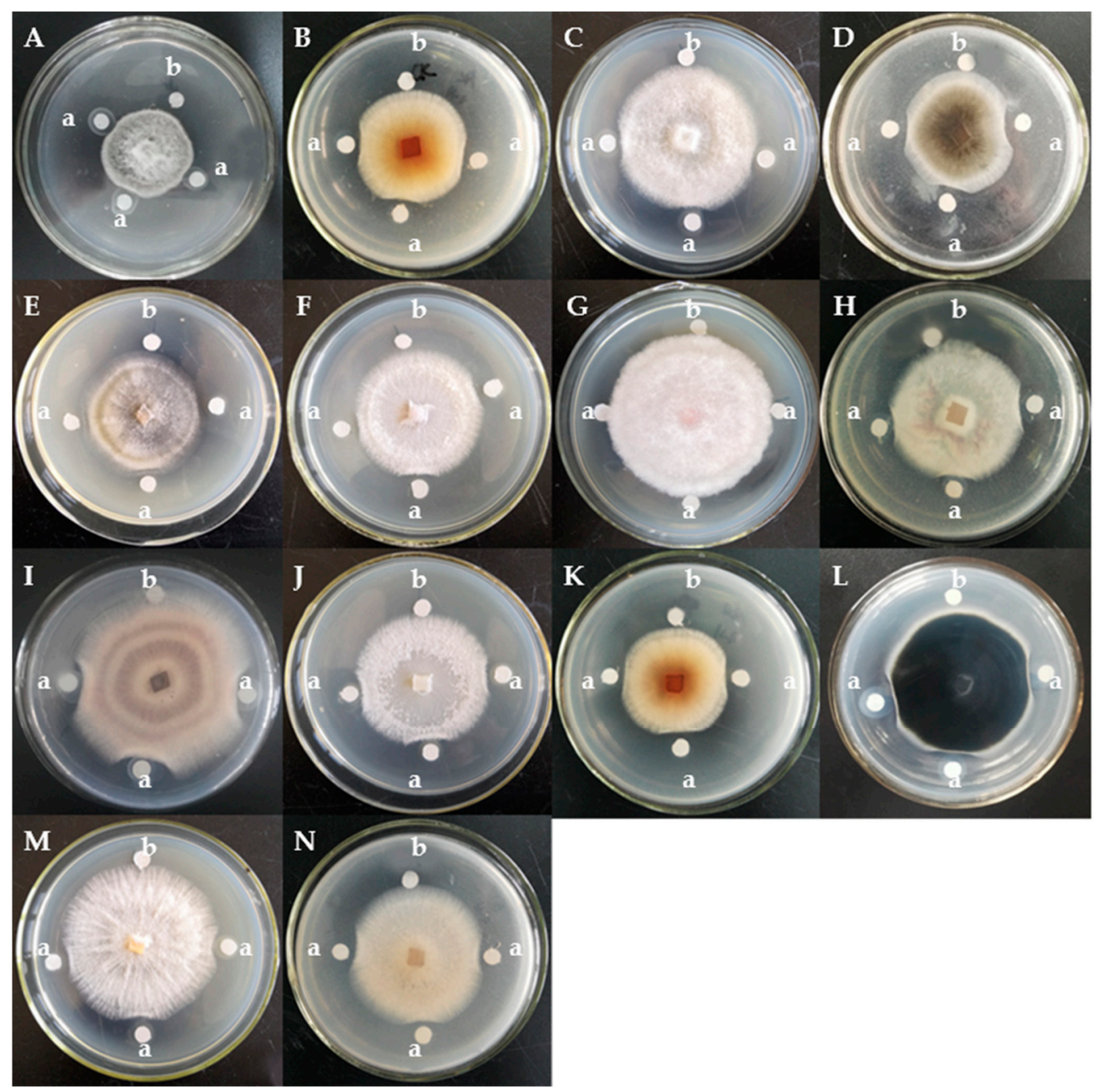

Figure 2. Growth inhibitory effects of BGAP represented by fraction SU3 toward 14 phytopathogenic fungi: (A) Alternaria longipes; (B) Botrytis cinerea; (C) Colletotrichum gloeosporioides; (D) Colletotrichum higginsianum; (E) Colletotrichum micotianae; (F) Exserohilum turcicum; (G) Fusarium graminearum; (H) Fusarium oxysporum; (I) Fusarium solani f. sp. glycines; (J) Helminthosporium maydis; (K) Magnaporthe oryzae; (L) Mycosphaerella arachidicola; (M) Pestalotiopsis microspora; and (N) Valsa mali; a: $20 \mu \mathrm{L}$ of BGAP solution $(1 \mathrm{mg} / \mathrm{mL}) ; \mathrm{b}: 20 \mu \mathrm{L}$ of PBS buffer. 


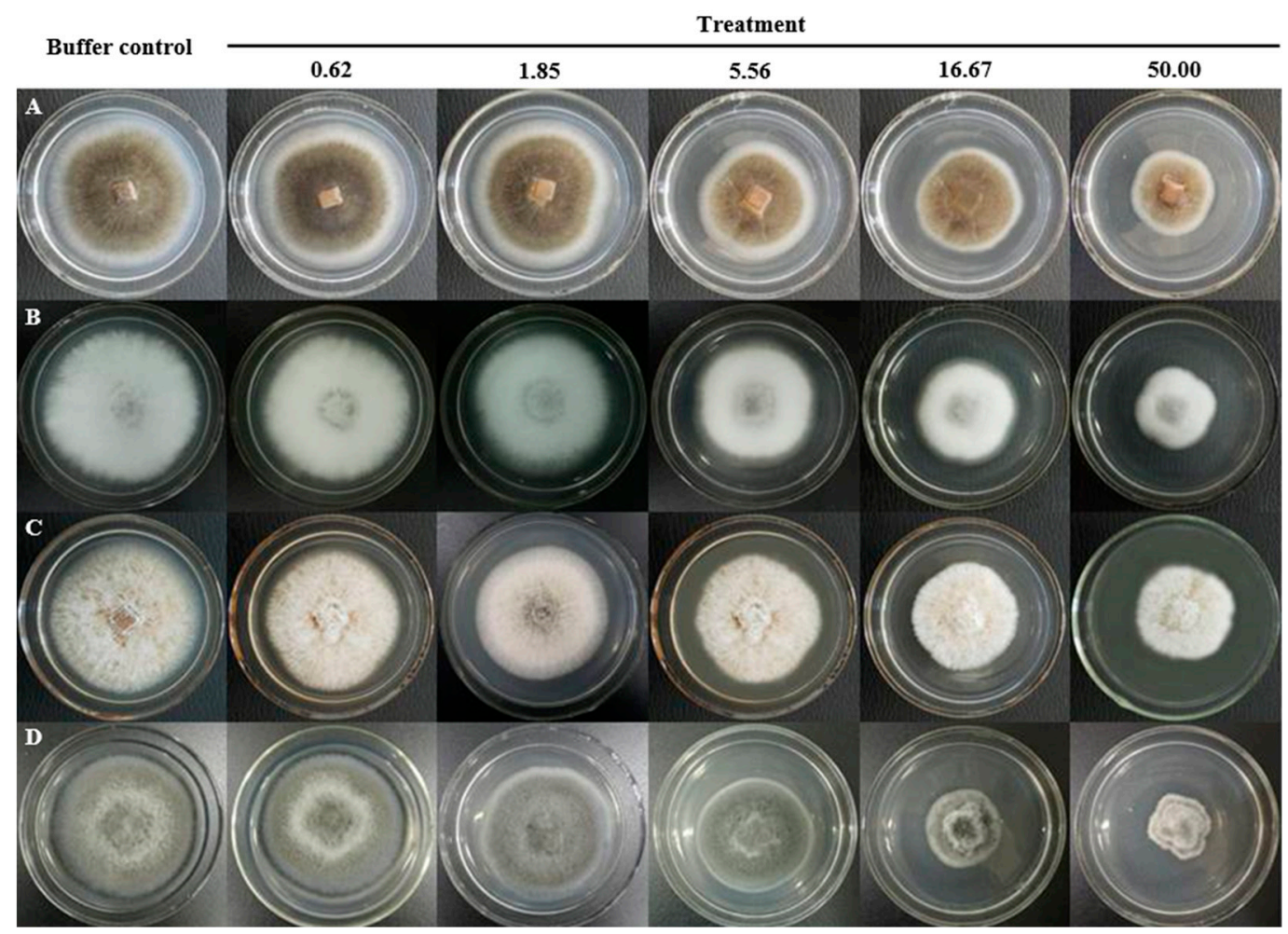

Figure 3. $\mathrm{IC}_{50}$ determination of BGAP toward four phytopathogenic fungi: (A) Colletotrichum higginsianum; (B) Exserohilum turcicum; (C) Magnaporthe oryzae; and (D) Mycosphaerella arachidicola; numerical value represents the concentration $(\mu \mathrm{g} / \mathrm{mL})$ of BGAP in the medium.

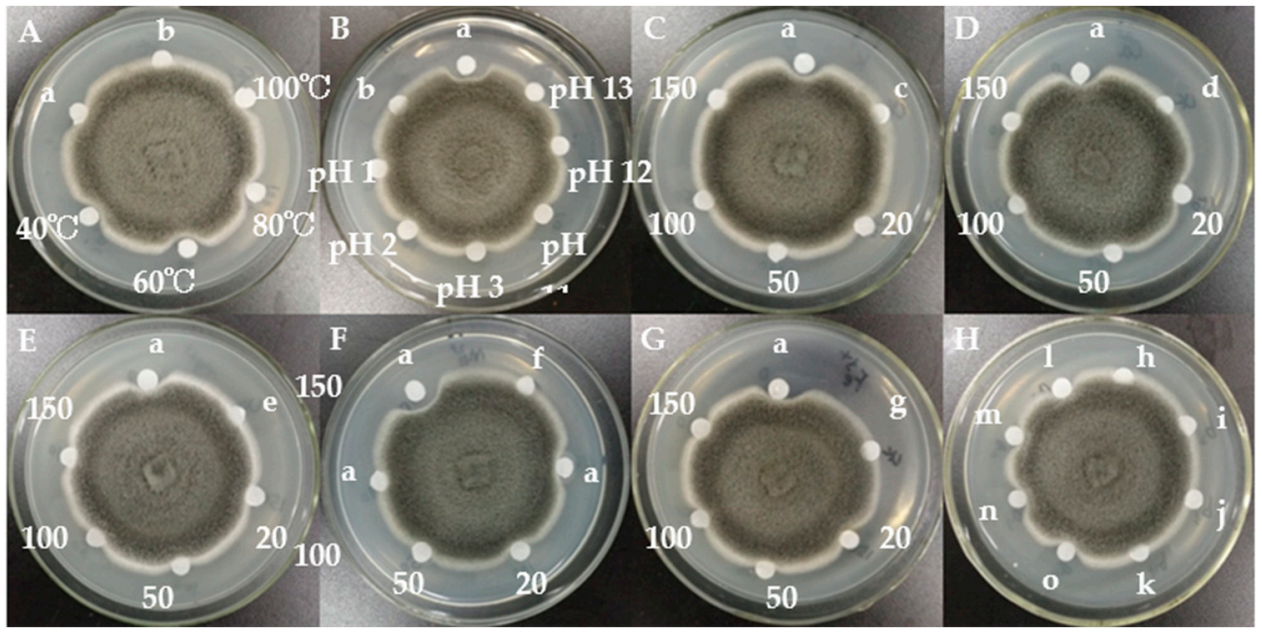

Figure 4. Effects of heat, acid-base, metal ions, and organic solvents on antifungal activity of BGAP: (A) heat treatment; (B) acid-base treatment; (C) treatment with $\mathrm{K}^{+}$ions; (D) treatment with $\mathrm{Ca}^{2+}$ ions; (E) treatment with $\mathrm{Mg}^{2+}$ ions; $(\mathbf{F})$ treatment with $\mathrm{Mn}^{2+}$ ions; $(\mathbf{G})$ treatment with $\mathrm{Fe}^{3+}$ ions; $(\mathbf{H})$ organic solvent treatment; a: $20 \mu \mathrm{L}$ of untreated BGAP solution; b: $20 \mu \mathrm{L}$ of PBS buffer; c: $20 \mu \mathrm{L}$ of $\mathrm{K}^{+}$solution (150 mmol/L); d: $20 \mu \mathrm{L}$ of $\mathrm{Ca}^{2+}$ solution $(150 \mathrm{mmol} / \mathrm{L})$; e: $20 \mu \mathrm{L}$ of $\mathrm{Mg}^{2+}$ solution $(150 \mathrm{mmol} / \mathrm{L})$; f: $20 \mu \mathrm{L}$ of $\mathrm{Mn}^{2+}$ solution (150 mmol/L); g: $20 \mu \mathrm{L}$ of $\mathrm{Fe}^{3+}$ solution $(150 \mathrm{mmol} / \mathrm{L}) ; \mathrm{h}: 20 \mu \mathrm{L}$ of $10 \%$ methanol; i: $20 \mu \mathrm{L}$ of $10 \%$ ethanol; j: $20 \mu \mathrm{L}$ of $10 \%$ isopropanol; $\mathrm{k}$ : $20 \mu \mathrm{L}$ of $10 \%$ chloroform; $40-100{ }^{\circ} \mathrm{C}$ represents $20 \mu \mathrm{L}$ of BGAP solution treated at the corresponding temperature; $\mathrm{pH} 1-13$ represents $20 \mu \mathrm{L}$ of BGAP solution treated with the corresponding acid-base; $20-150$ represents $20 \mu \mathrm{L}$ of BGAP solution treated with each metal ion at concentration of $20-150 \mathrm{mmol} / \mathrm{L} ; \mathrm{l}, \mathrm{m}, \mathrm{n}$, o represent BGAP solution treated with $10 \%$ methanol, $10 \%$ ethanol, $10 \%$ isopropanol and $10 \%$ chloroform respectively; and the final concentration of BGAP in all treatment groups was $1 \mathrm{mg} / \mathrm{mL}$. 
The fluorescence staining experiments disclosed that following staining with SYTOX green, $\mathrm{H}_{2}$ DCFDA and Rhodamine 123, fluorescence was observed in the hyphae of the BGAP-treated group, but not in the hyphae of the control group (Figures 5-7). After staining with Congo red, the fluorescence intensity at the hyphal tips of the BGAP-treated group was significantly stronger than that of the control group (Figure 8), indicating that BGAP engendered an increase in cell membrane permeability, a rise in reactive oxygen species (ROS) production, a decline in mitochondrial membrane potential, and accumulation of chitin at the hyphal tips of Mycosphaerella arachidicola.

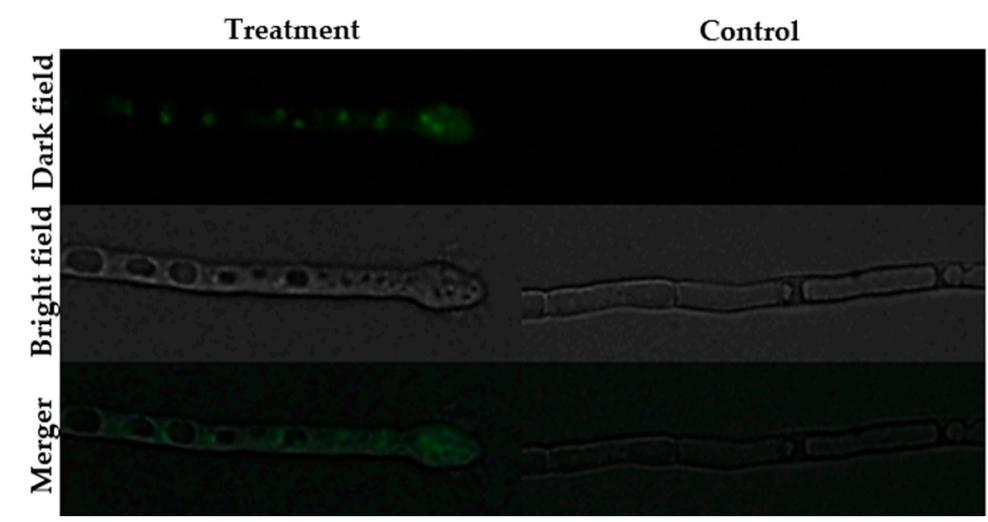

Figure 5. Permeabilization of Mycosphaerella arachidicola hyphal membrane caused by BGAP.

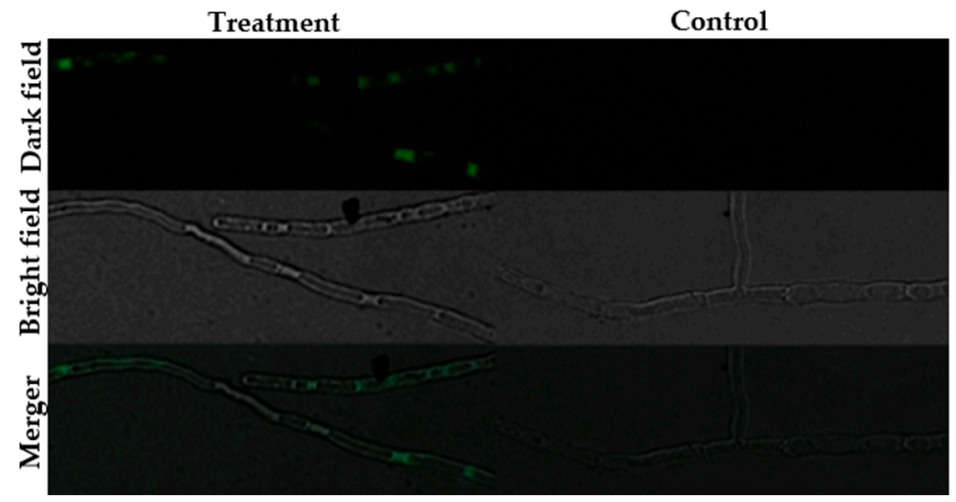

Figure 6. Increase in ROS production of Mycosphaerella arachidicola caused by BGAP.

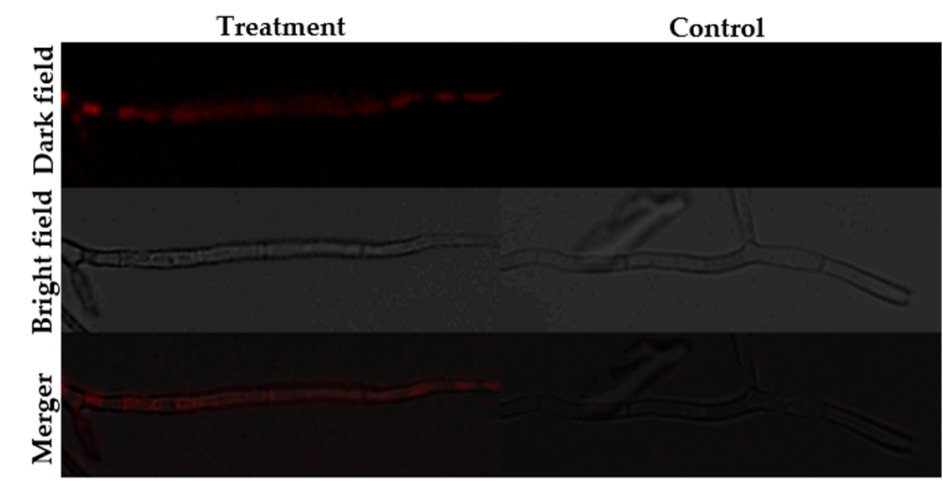

Figure 7. Decrease in mitochondrial membrane potential of Mycosphaerella arachidicola caused by BGAP. 


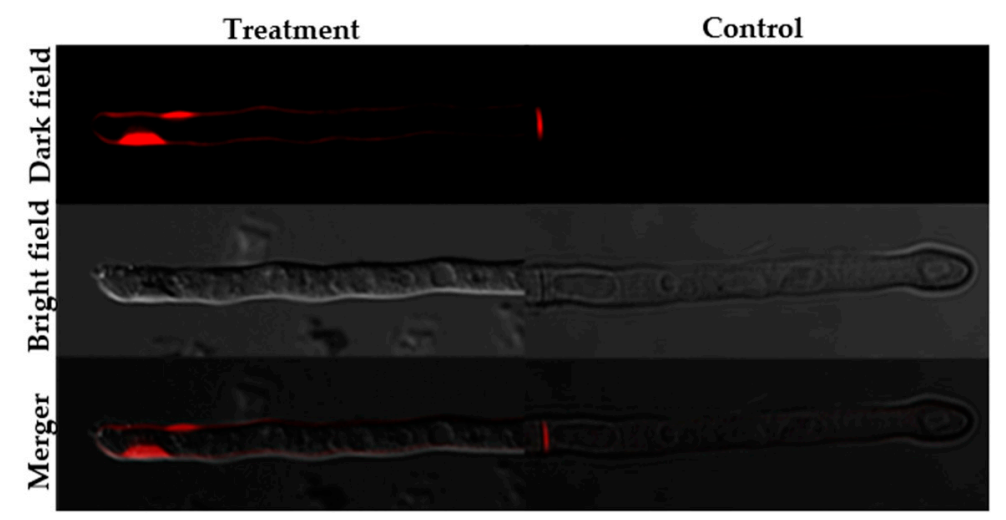

Figure 8. Accumulation of chitin at the hyphal tips of Mycosphaerella arachidicola caused by BGAP.

\section{Discussion}

The results of mass spectrometric analysis disclosed that BGAP was structurally similar to both defensins and thionins; therefore, we have listed the defensin peptides and thionin peptides recently isolated from plants in Table 2. In terms of antimicrobial activity, BGAP exhibits some similarities and differences compared with them. Among defensin-like peptides, Tf-AFP inhibited growth in Fusarium oxysporum [19]. Large pinto bean defensin exerted an inhibitory action on Fusarium oxysporum and Mycosphaerella arachidicola [21]. Legumi secchi peptide displayed inhibitory activity against Fusarium oxysporum, Helminthosporium maydis and Mycosphaerella arachidicola [22]. Limyin demonstrated inhibitory activity against Botrytis cinerea [23]. BGAP also evinced inhibitory activity against the above pathogenic fungi. On the contrary, limyin did not exhibit significant suppressive activity on Staphylococcus aureus and Salmonella sp. Similarly, BGAP did not have antibacterial activity against the eight bacterial species tested including Gram-positive and Gram-negative bacteria. Both large pinto bean defensin and the legumi secchi peptide were devoid of suppressive activity on Valsa mali. In contrast, BGAP inhibited Valsa mali, indicating that BGAP has a wider spectrum of antifungal action. Thionin-like peptides inhibited and killed fungi as well as Gram-positive and Gram-negative bacteria [24-27]. The antimicrobial activity of thionins could be inhibited by metal ions $[28,29]$. However, BGAP was devoid of antibacterial activity and also exhibited certain antifungal activityafter treatment with solutions containing $\mathrm{K}^{+}, \mathrm{Ca}^{2+}, \mathrm{Mg}^{2+}, \mathrm{Mn}^{2+}$ or Fe ${ }^{3+}$ ions. From this perspective, BGAP resembles defensins more than thionins. Table 3 lists the antifungal proteins and peptides previously isolated from Brassica spp. The molecular weights of juncin, brassiparin and kale peptides were $18.9 \mathrm{kDa}, 5716 \mathrm{Da}$, and $5907 \mathrm{Da}$ [30-32], respectively, while the molecular weight of BGAP was $8.5 \mathrm{kDa}$, which was closer to those of campesin $(9.4 \mathrm{kDa})$ and nsLTP $(9414 \mathrm{Da})[33,34]$. However, both campesin and nsLTP were similar in sequence to lipid transfer protein, while BGAP was structurally similar to defensin, indicating that BGAP is a peptide different from the abovementioned peptides. Nevertheless, BGAP exhibited a broad spectrum of antifungal activity and pronounced stability, which is similar to all of the antifungal proteins and peptides from Brassica spp. In addition, compared to previous reports, we have conducted more research on BGAP in terms of the mode of antifungal action. 
Table 2. Comparison of antimicrobial activity of BGAP with defensin-like peptides and thionin-like peptides isolated from other plants.

\begin{tabular}{|c|c|c|c|c|}
\hline Type & Peptide & Species of Origin & Antimicrobial Activity Toward Fungi or Bacteria & Ref. \\
\hline \multirow{5}{*}{$\begin{array}{l}\text { Defensin-like } \\
\text { peptide }\end{array}$} & BGAP & $\begin{array}{l}\text { Brassica oleracea var. } \\
\text { gongylodes }\end{array}$ & $\begin{array}{l}\text { Fungi: Colletotrichum higginsianum }\left(17.33 \mu \mathrm{g} / \mathrm{mL}^{a}\right) \text {, Exserohilum turcicum }\left(12.37 \mu \mathrm{g} / \mathrm{mL}^{a}\right) \text {, } \\
\text { Magnaporthe oryzae }\left(16.81 \mu \mathrm{g} / \mathrm{mL}^{a}\right) \text {, Mycosphaerella arachidicola }\left(5.60 \mu \mathrm{g} / \mathrm{mL}^{a}\right) \text {, etc. }\end{array}$ & This study \\
\hline & Tf-AFP & Trigonella foenum-graecum & Fungi: Fusarium oxysporum, Fusarium solani, Rhizoctonia solani & [19] \\
\hline & $\begin{array}{l}\text { Large pinto bean } \\
\text { defensin }\end{array}$ & Phaseolus vulgaris & $\begin{array}{l}\text { Fungi: Bipolaris maydis, Fusarium oxysporum, Mycosphaerella arachidicola, Setosphaeria turcica, } \\
\text { Valsa mali (no effect) }\end{array}$ & [21] \\
\hline & Legumi secchi peptide & Phaseolus vulgaris & $\begin{array}{l}\text { Fungi: Fusarium oxysporum }\left(9.2 \mu \mathrm{M}^{a}\right) \text {, Helminthosporium maydis }\left(9.5 \mu \mathrm{M}^{a}\right) \text {, } \\
\text { Mycosphaerella arachidicola }\left(1 \mu \mathrm{M}^{a}\right) \text {, Rhizoctonia solani }\left(3.5 \mu \mathrm{M}^{a}\right) \text {, Valsa mali (no effect) }\end{array}$ & [22] \\
\hline & Limyin & Phaseolus limensis & $\begin{array}{l}\text { Fungi: Alternaria alternata, Botrytis cinerea, Fusarium solani }\left(8.6 \mu \mathrm{M}^{a}\right), \text { Mycosphaerella arachidicola } \\
\text { (no effect), Pythium aphanidermatum (no effect) } \\
\text { Bacteria: Staphylococcus aureus (no effect), Salmonella sp. (no effect) }\end{array}$ & [23] \\
\hline \multirow{4}{*}{$\begin{array}{l}\text { Thionin-like } \\
\text { peptide }\end{array}$} & NsW2 & Nigella sativa & $\begin{array}{c}\text { Fungi: Candida albicans }\left(1.63 \mu \mathrm{M}^{a}\right) \\
\text { Bacteria: Bacillus subtilis }\left(1.63 \mu \mathrm{M}^{a}\right) \text {, Escherichia coli }\left(>26.0 \mu \mathrm{M}^{a}\right) \text {, Staphylococcus aureus }\left(3.25 \mu \mathrm{M}^{a}\right)\end{array}$ & [24] \\
\hline & $\begin{array}{l}\text { Capsicum annuum } \\
\text { peptide }\end{array}$ & Capsicum аппиит & $\begin{array}{l}\text { Fungi: Candida albicans }\left(96 \% \%^{b}, 100 \mu \mathrm{g} / \mathrm{mL}^{c}\right), \text { Candida tropicalis }\left(100 \% \%^{b}, 100 \mu \mathrm{g} / \mathrm{mL}^{c}\right) \\
\text { Saccharomyces cerevisiae }\left(98 \%^{b}, 100 \mu \mathrm{g} / \mathrm{mL}^{c}\right) \\
\text { Bacteria: Escherichia coli }\left(18 \% \%^{b}, 100 \mu \mathrm{g} / \mathrm{mL}^{c}\right), \text { Pseudomonas aeruginosa }\left(10 \%{ }^{b}, 100 \mu \mathrm{g} / \mathrm{mL}^{c}\right)\end{array}$ & [25] \\
\hline & Cp-thionin II & Vigna unguiculata & $\begin{array}{l}\text { Bacteria: Escherichia coli }\left(64 \mu \mathrm{g} / \mathrm{mL}^{d}\right) \text {, Pseudomonas syringae }\left(42 \mu \mathrm{g} / \mathrm{mL}^{d}\right) \text {, Staphylococcus aureus } \\
\left(128 \mu \mathrm{g} / \mathrm{mL}^{d}\right) \text {, Erwinia sp. (no effect), Ralstonia solanacearum (no effect); Rhataybacter } \mathrm{sp} \text {. (no effect) }\end{array}$ & [26] \\
\hline & Tu-AMP 1 & Tulipa gesneriana & $\begin{array}{c}\text { Fungi: Fusarium oxysporum }\left(2 \mu \mathrm{g} / \mathrm{mL}^{a}\right), \text { Geotrichum candidum }\left(2 \mu \mathrm{g} / \mathrm{mL}^{a}\right) \\
\text { Agrobacterium radiobacter }\left(15 \mu \mathrm{g} / \mathrm{mL}^{a}\right) \\
\text { Bacteria: Agrobacterium rhizogenes }\left(20 \mu \mathrm{g} / \mathrm{mL}^{a}\right) \text {, Curtobacterium flaccumfaciens }\left(13 \mu \mathrm{g} / \mathrm{mL}^{a}\right), \\
\text { Clavibacter michiganensis }\left(14 \mu \mathrm{g} / \mathrm{mL}^{a}\right), \text { Erwinia carotovora }\left(11 \mu \mathrm{g} / \mathrm{mL}^{a}\right)\end{array}$ & [27] \\
\hline
\end{tabular}

Table 3. Comparison of characteristics of BGAP with antifungal proteins and peptides isolated from Brassica spp.

\begin{tabular}{|c|c|c|c|c|c|c|}
\hline Protein/Peptide & Species of Origin & Mol (wt) & Antifungal Activity & Stability & Reported Effect & Ref. \\
\hline BGAP & Brassica oleracea var. gongylodes & $8.5 \mathrm{kDa}$ & $\begin{array}{c}\text { Colletotrichum higginsianum }(16.94 \mu \mathrm{g} / \mathrm{mL}) \\
\text { Exserohilum turcicum }(12.30 \mu \mathrm{g} / \mathrm{mL}) \\
\text { Magnaporthe oryzae }(16.45 \mu \mathrm{g} / \mathrm{mL}), \\
\text { Mycosphaerella arachidicola }(5.70 \mu \mathrm{g} / \mathrm{mL}), \text { etc. }\end{array}$ & $\begin{array}{l}40-100{ }^{\circ} \mathrm{C} \text {; pH 1-3, } \\
\text { pH } 11-13 \text {; methanol, } \\
\text { ethanol, isopropanol, } \\
\text { chloroform }(10 \%) \text {; } \\
\mathrm{Ca}^{2+}, \mathrm{Fe}^{3+}, \mathrm{K}^{+}, \mathrm{Mg}^{2+} \\
\quad(20-150 \mathrm{mM})\end{array}$ & $\begin{array}{l}\text { Accumulation of chitin at the tip of } \\
\text { mycelium, membrane permeabilization, } \\
\text { change of mitochondrial membrane } \\
\text { potential, ROS generation }\end{array}$ & This study \\
\hline Juncin & Brassica juncea var. integrifolia & $18.9 \mathrm{kDa}$ & $\begin{array}{c}\text { Fusarium oxysporum }(13.5 \mu \mathrm{M}), \\
\text { Helminthosporium maydis }(27 \mu \mathrm{M}), \\
\text { Mycosphaerella arachidicola }(10 \mu \mathrm{M}), \\
\text { Candida albicans }\end{array}$ & Not tested & $\begin{array}{l}\text { No membrane permeabilization (toward } \\
\text { Candida albicans) and chitin deposition } \\
\text { (toward Mycosphaerella arachidicola) }\end{array}$ & [30] \\
\hline
\end{tabular}


Table 3. Cont.

\begin{tabular}{|c|c|c|c|c|c|c|}
\hline Protein/Peptide & Species of Origin & Mol (wt) & Antifungal Activity & Stability & Reported Effect & Ref. \\
\hline Brassiparin & $5716 \mathrm{kDa}$ & $\begin{array}{l}\text { Brassica } \\
\text { parachinensis }\end{array}$ & $\begin{array}{c}\text { Fusarium oxysporum }(3.9 \mu \mathrm{M}), \\
\text { Helminthosporium maydis }(4.7 \mu \mathrm{M}), \\
\text { Mycosphaerella arachidicola }(2.6 \mu \mathrm{M}), \\
\text { Valsa mali }(0.22 \mu \mathrm{M})\end{array}$ & $\begin{array}{c}40-100^{\circ} \mathrm{C} ; \mathrm{pH} 1-3 \\
\mathrm{pH} 11-13\end{array}$ & Not tested & [31] \\
\hline Kale peptide & Brassica alboglabra & $5907 \mathrm{Da}$ & $\begin{array}{c}\text { Fusarium oxysporum }(4.3 \mu \mathrm{M}), \\
\text { Helminthosporium maydis }(2.1 \mu \mathrm{M}), \\
\text { Mycosphaerella arachidicola }(2.4 \mu \mathrm{M}), \\
\text { Valsa mali }(0.15 \mu \mathrm{M})\end{array}$ & $\begin{array}{c}20-80^{\circ} \mathrm{C} ; \mathrm{pH} 2-3 \\
\mathrm{pH} 10-11\end{array}$ & Not tested & [32] \\
\hline Campesin & Brassica campestris & $9.4 \mathrm{kDa}$ & $\begin{array}{l}\text { Fusarium oxysporum }(5.1 \mu \mathrm{M}), \\
\text { Mycosphaerella arachidicola }(4.4 \mu \mathrm{M})\end{array}$ & $0-100{ }^{\circ} \mathrm{C} ; \mathrm{pH}$ 0-14 & Not tested & [33] \\
\hline nsLTP & Brassica campestris & $9414 \mathrm{Da}$ & $\begin{array}{c}\text { Fusarium oxysporum }(8.3 \mu \mathrm{M}), \\
\text { Helminthosporium staivum, } \\
\text { Mycosphaerella arachidicola }(4.5 \mu \mathrm{M}), \\
\text { Sclerotinia sclerotiorum, Verticivium albotarum }\end{array}$ & $\begin{array}{c}20-100^{\circ} \mathrm{C} ; \mathrm{pH} 0-4 \\
\mathrm{pH} 9-14\end{array}$ & Not tested & [34] \\
\hline
\end{tabular}

a: Antifungal activity is represented by the half maximal inhibitory concentration. 
BGAP may undermine the growth of fungi by enhancing cell membrane permeability, boosting the production of ROS and disrupting mitochondrial membrane potential. The action of permeabilizing the fungal cell membrane is analogous to the legium secchi peptide, NsW2, and Capsicum annuum peptide listed in Table 2. Membrane permeabilization may involve fusion of antifungal peptide with the cell wall and cell membrane [35-37]. Several models related to membrane permeabilization have been proposed, such as the barrel-stave pore model, carpet model and thoroidal pore model [38]. Excessive production of ROS and decline of mitochondrial membrane potential may further trigger apoptosis of mycelial cells, since ROS plays a central role in the regulation of apoptosis [39], and mitochondrial membrane potential acts as a marker of early apoptosis [40]. Cellular ROS accumulation can ensue in the opening of mitochondrial permeability transition pores, leading to a fall in mitochondrial membrane potential and release of cytochrome c [39-41]. Cytochrome c interacts with apoptotic protease-activating factor, which in turn initiates a cascade of caspase activation to bring about apoptosis [42]. BGAP can also induce chitin deposition at the mycelial tip, which is reminiscent of the action of cabbage protein, Fava bean protein VFTI-E1 and Peltophorum ptercoarpum antifungal amidase [43-45]. However, the accumulation of chitin at the tip of the mycelium may be a factor that hinders mycelial growth and may also be a countermeasure adopted by pathogenic fungi against antifungal peptides [46]. At present, it is not clear which of the above phenomena mainly accounts for the observed inhibition of fungal growth. How these phenomena are triggered and whether there are more correlations between the phenomena remain to be studied.

To recapitulate, we report herein the isolation and characterization of a potent and stable antifungal peptide with exploitable potential from the seeds of Brassica oleracea var. gongylodes.

\section{Materials and Methods}

\subsection{Materials}

Kohlrabi seeds collected in Beijing, China were purchased from a seed vendor. The SP-Sepharose, Mono S 5/50 GL and Superdex peptide 10/300 GL columns used for chromatography were purchased from GE Healthcare (Piscataway, NJ, USA). The 14 phytopathogenic fungi including Alternaria longipes, Botrytis cinerea, Colletotrichum gloeosporioides, C. higginsianum, C. micotianae, Exserohilum turcicum, Fusarium graminearum, F. oxysporum, F. solani f. sp. glycines, Helminthosporium maydis, Magnaporthe oryzae, Mycosphaerella arachidicola, Pestalotiopsis microspora, and Valsa mali used in the following experiments were provided by Key Laboratory of Biopesticide and Chemical Biology, Fujian Agriculture and Forestry University. Eight bacterial species comprising Bacillus subtilis, Erwinia carotovora, Escherichia coli, Pseudomonas aeruginosa, P. pseudoalcaligenes, Ralstonia solanacearum, Salmonella sp., and Staphylococcus aureus utilized in the experiments described below were obtained from the same aforementioned source.

\subsection{Purification of the Antifungal Peptide BGAP}

Seeds (150 g) were immersed overnight in $1 \mathrm{~L}$ of $10 \mathrm{mM} \mathrm{NH}_{4} \mathrm{OAc}$ buffer (pH 4.6), homogenized and then left at $4{ }^{\circ} \mathrm{C}$ for $12 \mathrm{~h}$. The homogenate was centrifuged $\left(10000 \times g, 4{ }^{\circ} \mathrm{C}, 30 \mathrm{~min}\right)$. The resulting supernatant was filtered through four layers of gauze, and the filtrate was collected to obtain a crude extract. The crude extract was chromatographed on a column $(5 \mathrm{~cm} \times 16 \mathrm{~cm})$ of SP-Sepharose which had previously been equilibrated with $10 \mathrm{mM} \mathrm{NH}_{4} \mathrm{OAc}$ buffer ( $\mathrm{pH}$ 4.6). After the unadsorbed proteins had been eluted from the column, the adsorbed proteins were eluted successively with $10 \mathrm{mM} \mathrm{NH} \mathrm{m}_{4} \mathrm{OAc}$ buffer ( $\mathrm{pH}$ 4.6) containing $0.2 \mathrm{~mol} / \mathrm{L}, 0.5 \mathrm{~mol} / \mathrm{L}$, and $1 \mathrm{~mol} / \mathrm{L} \mathrm{NaCl}$. The active fractions with antifungal activity were dialyzed against double-distilled water in a dialysis bag with a molecular weight cut-off of $3500 \mathrm{Da}$ and then freeze-dried into powder form. The protein powders were redissolved in $10 \mathrm{mM} \mathrm{NH}{ }_{4} \mathrm{OAc}$ buffer ( $\mathrm{pH}$ 4.6), followed by ion exchange chromatography using a Mono S 5/50 GL column attached to the AKTA Purifier system (GE Healthcare). The column had been pre-equilibrated with $10 \mathrm{mM} \mathrm{NH}_{4} \mathrm{OAc}$ buffer ( $\mathrm{pH}$ 4.6) and the adsorbed proteins were 
eluted with $\mathrm{NH}_{4} \mathrm{OAc}$ buffer containing a linear gradient of $0-1 \mathrm{~mol} / \mathrm{L} \mathrm{NaCl}$. The active fractions were collected, dialyzed, lyophilized, and redissolved in $\mathrm{NH}_{4} \mathrm{OAc}$ buffer and then subjected to gel filtration chromatography using a Superdex peptide 10/300 GL column attached to the AKTA Purifier system (GE Healthcare, Piscataway, NJ, USA). The absorption peaks SP3, MS3, and SU3 obtained from the various stages of chromatography contained an antifungal peptide with gradually increasing purity.

\subsection{Molecular Weight Determination by Tricine-SDS-PAGE, Mass Spectrometry and Determination of Concentration of Antifungal Peptide}

The molecular weight of the antifungal peptide was determined by tricine-sodium dodecyl sulfate-polyacrylamide gel electrophoresis (tricine-SDS-PAGE) with a slight modification of the method provided by Schagger [47]. Briefly, the antifungal peptide sample was mixed with loading buffer containing $24 \%$ glycerol, $3 \% \beta$-mercaptoethanol, 10\% SDS, $0.02 \%$ Coomassie brilliant blue G-250 and $0.1 \mathrm{~mol} / \mathrm{L}$ Tris buffer ( $\mathrm{pH}$ 6.8) in a ratio of 4:1 (vol:vol), followed by boiling in water for $5 \mathrm{~min}$. The supernatant was removed for electrophoresis. In the electrophoresis, $4 \%$ stacking gel, $10 \%$ spacer gel and $16.5 \%$ separating gel were used, and gel staining was performed by employing the Coomassie brilliant blue method. After the gel had been destained, the antifungal peptide band in the gel was excised and sent to Shanghai Applied Protein Technology Co., Ltd (Shanghai, China) for matrix-assisted laser desorption/ionization with time-of-flight/time-of-flight mass spectrometry (MALDI-TOF/TOF MS) by using a 5800 MALDI-TOF/TOF mass spectrometric instrument (AB SCIEX, Framingham, MA, USA). Briefly, the sample in the gel was enzymatically hydrolyzed in a sequencing grade trypsin solution at $37^{\circ} \mathrm{C}$ for $20 \mathrm{~h}$. After the enzymatic hydrolysate was removed, $0.1 \%$ TFA in $60 \%$ acetonitrile was added to the gel and sonicated for $15 \mathrm{~min}$. Subsequently, the enzymatic hydrolysate was combined and desalted by using a ZipTip tip. The sample solution $(1 \mu \mathrm{L})$ was added to the sample target and allowed to dry naturally, and then $0.6 \mu \mathrm{L}$ of supersaturated CHCA matrix solution (dissolved in $0.1 \%$ TFA in $50 \%$ acetonitrile) was added, dried naturally, and analyzed by employing a MALDI-TOF-TOF analyzer. The information regarding the resulting peptide fragments was subjected to a database search using Mascot 2.2 software against NCBInr databases. The peptide concentration used in all experiments was measured with the BCA method using a kit.

\subsection{Assay of Antifungal Activity}

Pathogenic fungi were inoculated on a PDA medium plate (90 $\mathrm{mm} \times 15 \mathrm{~mm}$ culture dish) and cultured at $28^{\circ} \mathrm{C}$. When each fungal mycelium had grown to a diameter of $4-5 \mathrm{~cm}$, four sterile filter paper disks, each with a diameter of $6 \mathrm{~mm}$, were placed $5 \mathrm{~mm}$ from the periphery of the mycelial colony. An antifungal peptide solution at a concentration of $1 \mathrm{mg} / \mathrm{mL}$ was prepared in $20 \mathrm{mmol} / \mathrm{L}$ phosphate buffered saline (PBS) buffer ( $\mathrm{pH}$ 7.0). Then $20 \mu \mathrm{L}$ of the antifungal peptide solution were added to each of the three paper disks, and another $20 \mu \mathrm{L}$ of PBS buffer was added to the fourth paper disk as a blank control. After the treatment, the plates were continuously cultured at $28^{\circ} \mathrm{C}$, and the growth status of each fungal mycelium was observed within 2-3 days [21].

\subsection{Assay of Antibacterial Activity}

Activated bacteria were inoculated on LB slant medium and cultured at $37{ }^{\circ} \mathrm{C}$ for $20 \mathrm{~h}$. The bacterial suspension was prepared by washing the lawn with a $0.9 \%(w / v) \mathrm{NaCl}$ solution, and the $\mathrm{OD}_{600}$ value of the bacterial suspension was adjusted to 1.0. $\mathrm{LB}$ medium $(15 \mathrm{~mL})$ was poured into the petri dish, and sterile Oxford cups $(8 \mathrm{~mm} \times 10 \mathrm{~mm})$ were placed on the plateafter solidification. A $1 \mathrm{~mL}$ aliquot of the bacterial suspension was added to $14 \mathrm{~mL}$ of $\mathrm{LB}$ medium $(0.7 \%$ agar), cooled to about $50{ }^{\circ} \mathrm{C}$, mixed well, poured into a plate, andafter it had solidified, the Oxford cups were taken out. Fifty microliters of antifungal peptide solution $(1 \mathrm{mg} / \mathrm{mL})$ were added to each of the three wells in each plate, and 50 microliters of PBS buffer was added to the fourth well as a control. The treated plate was placed at $4{ }^{\circ} \mathrm{C}$ for $6 \mathrm{~h}$ and then transferred to an incubator at $37^{\circ} \mathrm{C}$. After $16 \mathrm{~h}$ of culture, the inhibition zone on the plate was observed. 


\subsection{Assay of Stability of Antifungal Activity to Temperature Changes, $p H$ Changes and in Presence of Metal Chlorides}

An antifungal peptide solution at a concentration of $1 \mathrm{mg} / \mathrm{mL}$ was prepared in $20 \mathrm{mmol} / \mathrm{L}$ PBS buffer, and $100 \mu \mathrm{L}$ of antifungal peptide solution was placed in a water bath at $40-100{ }^{\circ} \mathrm{C}$ for $15 \mathrm{~min}$. Then the assay was performed to determine the stability of antifungal activity to heat treatment. An antifungal peptide solution at a concentration of $1 \mathrm{mg} / \mathrm{mL}$ was prepared in distilled water and was freeze-dried to dry powder. The peptide powder was redissolved in PBS buffer at $\mathrm{pH} 1-3$ and $\mathrm{pH} 11-13$, and placed at $25^{\circ} \mathrm{C}$ for $15 \mathrm{~min}$. Then the assay of antifungal activity was performed to determine the stability of the antifungal peptide to acid-base treatment. An antifungal peptide solution at a concentration of $2 \mathrm{mg} / \mathrm{mL}$ was prepared in $40 \mathrm{mmol} / \mathrm{L} \mathrm{PBS}$ buffer, and $50 \mu \mathrm{L}$ of the solution was added to $50 \mu \mathrm{L}$ of a solution containing $150 \mathrm{mmol} / \mathrm{L} \mathrm{KCl}, 150 \mathrm{mmol} / \mathrm{L} \mathrm{CaCl}_{2}$, $150 \mathrm{mmol} / \mathrm{L} \mathrm{MgCl}_{2}, 150 \mathrm{mmol} / \mathrm{L} \mathrm{MnCl}_{2}$ or $150 \mathrm{mmol} / \mathrm{L} \mathrm{FeCl}_{3}$. Then the assay of antifungal activity was performed to determine the stability of antifungal activity to treatment with metal ionsafter the mixture had been incubated at $25{ }^{\circ} \mathrm{C}$ for $2 \mathrm{~h}$. An antifungal peptide solution (concentration $2 \mathrm{mg} / \mathrm{mL}$ ) was prepared in $40 \mathrm{mmol} / \mathrm{L}$ PBS buffer, and $50 \mu \mathrm{L}$ of antifungal peptide solution was added to $50 \mu \mathrm{L}$ of solutions containing methanol, ethanol, isopropanol and chloroform at a concentration of $10 \%(v / v)$. Then the assay of antifungal activity was performed to determine the stability of antifungal activity to treatment with various organic solventsafter incubation of the mixture at $25{ }^{\circ} \mathrm{C}$ for $2 \mathrm{~h}$. In the above experiments, Mycosphaerella arachidicola was used as the test fungus.

\subsection{Assay of Antifungal Activity Based on the Half-maximal Inhibitory Concentration}

A solution of the antifungal peptide at a concentration of $250 \mu \mathrm{g} / \mathrm{mL}$ was prepared in PBS buffer and serially diluted three times. One milliliter of the antifungal peptide solution filtered through a $0.22 \mu \mathrm{m}$ sterile filter was added to $4 \mathrm{~mL}$ of PDA medium cooled to about $50^{\circ} \mathrm{C}$, and mixed and poured into a petri dish $(55 \mathrm{~mm} \times 15 \mathrm{~mm})$. A 5 -mm diameter of the fungus was cut at the edge of the activated fungal colony using a sterilizing punch and inoculated on the above plate. The inoculated plate was cultured at $28^{\circ} \mathrm{C}$, and the diameter of the mycelial colony of the pathogenic fungus was measured every $12 \mathrm{~h} \mathrm{[45].} \mathrm{In} \mathrm{the} \mathrm{control} \mathrm{group,} \mathrm{the} \mathrm{antifungal} \mathrm{peptide} \mathrm{solution} \mathrm{was} \mathrm{replaced} \mathrm{by} \mathrm{the} \mathrm{same}$ volume of PBS buffer, and there were three replicates in each of the treatment groups and the control group. The fungi tested included Colletotrichum higginsianum, Exserohilum turcicum, Magnaporthe oryzae and Mycosphaerella arachidicola. The growth inhibition rate was calculated using the following formula: (inhibition of fungal growth $=(1-$ mycelial colony area of treatment group/mycelial colony area of control group) $\times 100 \%$ ). The half maximal inhibitory concentration of the antifungal peptide against each pathogenic fungus was calculated by utilizing the GraphPad Prism 6 software (GraphPad Software, Inc., San Diego, CA, USA).

\subsection{Assays of Cell Membrane Permeability Changes, Reactive Oxygen Species Production, Mitochondrial Membrane Potential Changes and Chitin Accumulation in the Fungus Mycosphaerella arachidicola}

The fungal hyphae cultured in medium containing the antifungal peptide were stained with the fluorescent dyes SYTOX green, $\mathrm{H}_{2}$ DCFDA, Rhodamine 123, and Congo red, respectively, to perform assays of cell membrane permeability change, reactive oxygen species accumulation, mitochondrial membrane potential change, and chitin accumulation, respectively [22,45,48-50]. Mycosphaerella arachidicola was used as the test fungus. The test fungus was inoculated into PD liquid medium, and the antifungal peptide was added to a final concentration of $1 \mathrm{mg} / \mathrm{mLafter}$ culture with shaking $(150 \mathrm{rmp} / \mathrm{min})$ at a constant temperature $\left(28^{\circ} \mathrm{C}\right)$ for 2 days. The same volume of PBS buffer was added in the control group. The hyphae used for SYTOX green, $\mathrm{H}_{2}$ DCFDA and Rhodamine 123 staining were collectedafter $12 \mathrm{~h}$ of culture, and the hyphae used for Congo red staining was collectedafter $24 \mathrm{~h}$ of cultivation. The hyphae were resuspended in $500 \mu \mathrm{L}$ of PBS buffer, then mixed with $1 \mu \mathrm{L}$ of fluorescent dye and stained for $30 \mathrm{~min}$ in the dark. After excess stain had been removed by washing with PBS buffer, the hyphae were picked to prepare smears, and the staining results 
were observed under a fluorescence microscope. Among the above fluorescent dyes, SYTOX green is a high-affinity nucleic acid dye that can enter cells when the plasma membrane is damaged, and the concentration used in the experiment was $5 \mathrm{mmol} / \mathrm{mL} . \mathrm{H}_{2} \mathrm{DCFDA}$ is a cell osmotic indicator of ROS that fluorescesafter deacetylation by intracellular esters and oxidation by ROS, and the concentration used in the experiment was $2 \mathrm{mg} / \mathrm{mL}$. Rhodamine 123 is a cationic fluorescent dye that can penetrate cell membranes. It can rely on the mitochondrial transmembrane potential to enter the mitochondrial matrix in normal cells. Then the fluorescence intensity will become attenuated or disappear. The concentration of Rhodamine 123 used in the experiment was $2 \mathrm{mg} / \mathrm{mL}$. Congo red can be tightly bound to chitin, and the concentration used in the experiment was $1.5 \mathrm{mg} / \mathrm{mL}$.

Author Contributions: Formal analysis, S.Y.; Investigation, C.W. and Y.Z.; Methodology, W.Z.; Project administration, X.Y.; Writing — original draft, C.W., T.N. and X.Y.

Funding: This research was funded by the University-Industry Cooperation Project of Fujian Provincial Department of Science and Technology, grant number 2018N5005.

Conflicts of Interest: The authors declare no conflict of interest.

\section{References}

1. Fisher, M.C.; Henk, D.A.; Briggs, C.J.; Brownstein, J.S.; Madoff, L.C.; McCraw, S.L.; Gurr, S.J. Emerging fungal threats to animal, plant and ecosystem health. Nature 2012, 484, 186-194. [CrossRef] [PubMed]

2. Godfray, H.C.J.; Mason-D'Croz, D.; Robinson, S. Food system consequences of a fungal disease epidemic in a major crop. Philos. Trans R. Soc. B Biol. Sci. 2016, 371. [CrossRef]

3. Pitt, J.I.; Miller, J.D. A concise history of mycotoxin research. J. Agr. Food Chem. 2017, 65, 7021-7033. [CrossRef] [PubMed]

4. Liew, W.P.P.; Mohd-Redzwan, S. Mycotoxin: its impact on gut health and microbiota. Front Cell Infect Microbiol. 2018, 8. [CrossRef]

5. Hirooka, T.; Ishii, H. Chemical control of plant diseases. J. Gen. Plant Pathol. 2013, 79, 390-401. [CrossRef]

6. He, D.C.; Zhan, J.S.; Xie, L.H. Problems, challenges and future of plant disease management: From an ecological point of view. J. Integr. Agr. 2016, 15, 705-715. [CrossRef]

7. Hou, B.; Wu, L.H. Safety impact and farmer awareness of pesticide residues. Food Agr. Immunol. 2010, 21, 191-200. [CrossRef]

8. Price, C.L.; Parker, J.E.; Warrilow, A.G.S.; Kelly, D.E.; Kelly, S.L. Azole fungicides-understanding resistance mechanisms in agricultural fungal pathogens. Pest Manag. Sci. 2015, 71, 1054-1058. [CrossRef] [PubMed]

9. Meyer, V. A small protein that fights fungi: AFP as a new promising antifungal agent of biotechnological value. Appl. Microbiol. Biot. 2008, 78, 17-28. [CrossRef] [PubMed]

10. Kaur, J.; Sagaram, U.S.; Shah, D. Can plant defensins be used to engineer durable commercially useful fungal resistance in crop plants? Fungal Biol. Rev. 2011, 25, 128-135. [CrossRef]

11. Yan, J.; Yuan, S.S.; Jiang, L.L.; Ye, X.J.; Ng, T.B.; Wu, Z.J. Plant antifungal proteins and their applications in agriculture. Appl. Microbiol. Biot. 2015, 99, 4961-4981. [CrossRef] [PubMed]

12. Leiter, E.; Gall, T.; Csernoch, L.; Pocsi, I. Biofungicide utilizations of antifungal proteins of filamentous ascomycetes: current and foreseeable future developments. Biocontrol 2017, 62, 125-138. [CrossRef]

13. Lee, J.K.; Gopal, R.; Seo, C.H.; Cheong, H.; Park, Y. Isolation and purification of a novel deca-antifungal peptide from potato (Solanum tuberosum L. cv. Jopung) against Candida albicans. Int. J. Mol. Sci. 2012, 13, 4021-4032. [CrossRef] [PubMed]

14. Ibrahim, M.; Kaushik, N.; Sowemimo, A.; Chhipa, H.; Koekemoer, T.; van de Venter, M.; Odukoya, O.A. Antifungal and antiproliferative activities of endophytic fungi isolated from the leaves of Markhamia tomentosa. Pharm. Biol. 2017, 55, 590-595. [CrossRef] [PubMed]

15. Yan, H.; Yun, J.; Ai, D.; Zhang, W.; Bai, J.; Guo, J. Two novel cationic antifungal peptides isolated from Bacillus pumilus $\mathrm{HN}-10$ and their inhibitory activity against Trichothecium roseum. World J. Microb. Biot. 2018, 34. [CrossRef]

16. Mandal, S.M.; Migliolo, L.; Franco, O.L.; Ghosh, A.K. Identification of an antifungal peptide from Trapa natans fruits with inhibitory effects on Candida tropicalis biofilm formation. Peptides 2011, 32, 1741-1747. [CrossRef] [PubMed] 
17. Astafieva, A.A.; Rogozhin, E.A.; Andreev, Y.A.; Odintsova, T.I.; Kozlov, S.A.; Grishin, E.V.; Egorov, T.A. A novel cysteine-rich antifungal peptide ToAMP4 from Taraxacum officinale Wigg. flowers. Plant Physiol. Bioch. 2013, 70, 93-99. [CrossRef] [PubMed]

18. Mandal, S.M.; Porto, W.F.; Dey, P.; Maiti, M.K.; Ghosh, A.K.; Franco, O.L. The attack of the phytopathogens and the trumpet solo: identification of a novel plant antifungal peptide with distinct fold and disulfide bond pattern. Biochimie 2013, 95, 1939-1948. [CrossRef] [PubMed]

19. Oddepally, R.; Guruprasad, L. Isolation, purification, and characterization of a stable defensin-like antifungal peptide from Trigonella foenum-graecum (fenugreek) seeds. Biochemistry 2015, 80, 332-342. [CrossRef] [PubMed]

20. Rogozhin, E.A.; Slezina, M.P.; Slavokhotova, A.A.; Istomina, E.A.; Korostyleva, T.V.; Smirnov, A.N.; Grishin, E.V.; Egorov, T.A.; Odintsova, T.I. A novel antifungal peptide from leaves of the weed Stellaria media L. Biochimie 2015, 116, 125-132. [CrossRef]

21. Yin, C.; Wong, J.H.; $\mathrm{Ng}$, T.B. Isolation of a hemagglutinin with potent antiproliferative activity and a large antifungal defensin from Phaseolus vulgaris cv. hokkaido large pinto beans. J. Agr. Food Chem. 2015, 63, 5439-5448. [CrossRef] [PubMed]

22. Lam, S.K.; Ng, T.B. Purification and characterization of an antifungal peptide with potent antifungal activity but devoid of antiproliferative and HIV reverse transcriptase activities from legumi secchi beans. Appl. Biochem. Biotech. 2013, 169, 2165-2174. [CrossRef]

23. Wang, S.Y.; Rao, P.F.; Ye, X.Y. Isolation and biochemical characterization of a novel leguminous defense peptide with antifungal and antiproliferative potency. Appl. Microbiol. Biot. 2009, 82, 79-86. [CrossRef] [PubMed]

24. Vasilchenko, A.S.; Smirnov, A.N.; Zavriev, S.K.; Grishin, E.V.; Vasilchenko, A.V.; Rogozhin, E.A. Novel thionins from black seed (Nigella sativa L.) demonstrate antimicrobial activity. Int. J. Pept. Res. Ther. 2017, 23, 171-180. [CrossRef]

25. Taveira, G.B.; Mathias, L.S.; da Motta, O.V.; Machado, O.L.T.; Rodrigues, R.; Carvalho, A.O.; Teixeira-Ferreira, A.; Perales, J.; Vasconcelos, I.M.; Gomes, V.M. Thionin-like peptides from Capsicum annuum fruits with high activity against human pathogenic bacteria and yeasts. Biopolymers 2014, 102, 30-39. [CrossRef] [PubMed]

26. Franco, O.L.; Murad, A.M.; Leite, J.R.; Mendes, P.A.M.; Prates, M.V.; Bloch, C. Identification of a cowpea gamma-thionin with bactericidal activity. Febs J. 2006, 273, 3489-3497. [CrossRef] [PubMed]

27. Fujimura, M.; Ideguchi, M.; Minami, Y.; Watanabe, K.; Tadera, K. Purification, characterization, and sequencing of novel antimicrobial peptides, Tu-AMP 1 and Tu-AMP 2, from bulbs of tulip (Tulipa gesneriana L.). Biosci. Biotech. Bioch. 2004, 68, 571-577. [CrossRef]

28. De Lucca, A.J.; Cleveland, T.E.; Wedge, D.E. Plant-derived antifungal proteins and peptides. Can. J. Microbiol. 2005, 51, 1001-1014. [CrossRef]

29. Van der Weerden, N.L.; Bleackley, M.R.; Anderson, M.A. Properties and mechanisms of action of naturally occurring antifungal peptides. Cell Mol. Life Sci. 2013, 70, 3545-3570. [CrossRef]

30. Ye, X.; $\mathrm{Ng}$, T.B. Isolation and characterization of juncin, an antifungal protein from seeds of japanese takana (Brassica juncea var. integrifolia). J. Agr. Food Chem. 2009, 57, 4366-4371. [CrossRef]

31. Lin, P.; Ng, T.B. Brassiparin, an antifungal peptide from Brassica parachinensis seeds. J. Appl. Microbiol. 2009, 106, 554-563. [CrossRef]

32. Lin, P.; Ng, T.B. A novel and exploitable antifungal peptide from kale (Brassica alboglabra) seeds. Peptides 2008, 29, 1664-1671. [CrossRef]

33. Lin, P.; Wong, J.H.; Xia, L.; Ng, T.B. Campesin, a thermostable antifungal peptide with highly potent antipathogenic activities. J. Biosci. Bioeng. 2009, 108, 259-265. [CrossRef]

34. Lin, P.; Xia, L.; Wong, J.H.; Ng, T.B.; Ye, X.; Wang, S.; Shi, X. Lipid transfer proteins from Brassica campestris and mung bean surpass mung bean chitinase in exploitability. J. Pept. Sci. 2007, 13, 642-648. [CrossRef]

35. Thevissen, K.; Osborn, R.W.; Acland, D.P.; Broekaert, W.F. Specific, high affinity binding sites for an antifungal plant defensin on Neurospora crassa hyphae and microsomal membranes. J. Biol. Chem. 1997, 272, 32176-32181. [CrossRef]

36. Thevissen, K.; Warnecke, D.C.; Francois, E.J.A.; Leipelt, M.; Heinz, E.; Ott, C.; Zahringer, U.; Thomma, B.P.H.J.; Ferkel, K.K.A.; Cammue, B.P.A. Defensins from insects and plants interact with fungal glucosylceramides. J. Biol. Chem. 2004, 279, 3900-3905. [CrossRef] 
37. Cools, T.L.; Vriens, K.; Struyfs, C.; Verbandt, S.; Ramada, M.H.S.; Brand, G.D.; Bloch, C.; Koch, B.; Traven, A.; Drijfhout, J.W.; et al. The Antifungal plant defensin HsAFP1 is a phosphatidic acid-interacting peptide inducing membrane permeabilization. Front Microbiol. 2017, 8. [CrossRef]

38. Palffy, R.; Gardlik, R.; Behuliak, M.; Kadasi, L.; Turna, J.; Celec, P. On the physiology and pathophysiology of antimicrobial peptides. Mol. Med. 2009, 15, 51-59.

39. Aerts, A.M.; Bammens, L.; Govaert, G.; Carmona-Gutierrez, D.; Madeo, F.; Cammue, B.P.A.; Thevissen, K. The antifungal plant defensin HsAFP1 from Heuchera sanguinea induces apoptosis in Candida albicans. Front Microbiol. 2011, 2. [CrossRef]

40. Krysko, D.V.; Roels, F.; Leybaert, L.; D'Herde, K. Mitochondrial transmembrane potential changes support the concept of mitochondrial heterogeneity during apoptosis. J. Histochem. Cytochem. 2001, 49, 1277-1284. [CrossRef]

41. Circu, M.L.; Aw, T.Y. Reactive oxygen species, cellular redox systems, and apoptosis. Free Radical Bio. Med. 2010, 48, 749-762. [CrossRef] [PubMed]

42. Savitskaya, M.A.; Onishchenko, G.E. Mechanisms of apoptosis. Biochemistry 2015, 80, 1393-1405. [CrossRef]

43. Fang, E.F.; Hassanien, A.A.E.; Wong, J.H.; Bah, C.S.F.; Soliman, S.S.; Ng, T.B. Purification and modes of antifungal action by Vicia faba cv. egypt trypsin inhibitor. J. Agr. Food Chem. 2010, 58, 10729-10735. [CrossRef] [PubMed]

44. Lam, S.K.; Ng, T.B. First report of an antifungal amidase from Peltophorum ptercoarpum. Biomed. Chromatogr. 2010, 24, 458-464. [CrossRef] [PubMed]

45. Ye, X.J.; Ng, T.B.; Wu, Z.J.; Xie, L.H.; Fang, E.F.; Wong, J.H.; Pan, W.L.; Wing, S.S.C.; Zhang, Y.B. Protein from red cabbage (Brassica oleracea) seeds with antifungal, antibacterial, and anticancer activities. J. Agr. Food Chem. 2011, 59, 10232-10238. [CrossRef] [PubMed]

46. Delgado, J.; Owens, R.A.; Doyle, S.; Asensio, M.A.; Nunez, F. Increased chitin biosynthesis contributes to the resistance of Penicillium polonicum against the antifungal protein PgAFP. Appl. Microbiol. Biot. 2016, 100, 371-383. [CrossRef]

47. Schagger, H. Tricine-SDS-PAGE. Nat. Protoc. 2006, 1, 16-22. [CrossRef]

48. Brambila Vieira, M.E.; Vasconcelos, I.M.; Tavares Machado, O.L.; Gomes, V.M.; Carvalho, A.D.O. Isolation, characterization and mechanism of action of an antimicrobial peptide from Lecythis pisonis seeds with inhibitory activity against Candida albicans. Acta Bioch. Bioph. Sin. 2015, 47, 716-729. [CrossRef]

49. Ghosh, P.; Roy, A.; Hess, D.; Ghosh, A.; Das, S. Deciphering the mode of action of a mutant Allium sativum leaf agglutinin (mASAL), a potent antifungal protein on Rhizoctonia solani. Bmc Microbiol. 2015, 15. [CrossRef]

50. Wong, J.H.; Lau, K.M.; Wu, Y.O.; Cheng, L.; Wong, C.W.; Yew, D.T.W.; Leung, P.C.; Fung, K.P.; Hui, M.; $\mathrm{Ng}$, T.B.; et al. Antifungal mode of action of macrocarpal C extracted from Eucalyptus globulus Labill (Lan An) towards the dermatophyte Trichophyton mentagrophytes. Chin. Med. 2015, 10. [CrossRef]

Sample Availability: Samples of the compounds are not available from the authors.

(C) 2019 by the authors. Licensee MDPI, Basel, Switzerland. This article is an open access article distributed under the terms and conditions of the Creative Commons Attribution (CC BY) license (http:/ / creativecommons.org/licenses/by/4.0/). 